\title{
Introduction to the Special Issue on the Patterns of Interplay between Public and Private Food Regulation
}

\author{
Paul Verbruggen and Tetty Havinga*
}

This Special Issue aims to develop a deeper understanding of the interplay between public and private actors in the regulatory governance of food. It starts from the observation that the traditional concept of law as command-and-control legislation and law enforcement by national governmental bodies, including inspectorates and courts, is not adequate to capture today's world of food governance. Nowadays, a broad range of public and private entities acting at national and international level seek to shape and influence the production, trade and handling of food and the risks involved therein. Drawing on data from Europe and the United States, the contributions to this Special Issue seek to unravel the intimate, yet complex ties between public and private actors within governance arrangements regulating food safety and sustainability. The articles are focused around the various phases of the policy cycle for food governance, thus addressing the interaction in stages of agenda-setting and rule-making, adoption and implementation, monitoring and enforcement, and evaluation and review. In descriptive terms, each contribution lays out the 'who' (actors), the 'what' (activity), the 'why' (rationale) and the 'how' (instruments) of food governance. In evaluative terms, the papers discuss and explain the results and challenges of the design of the publicprivate governance arrangements. Jointly, the contributions offer original and invaluable empirical insights explaining the rise, design and challenges of mixed governance arrangements in the food sector.

\section{Setting the Scene: Transitions in Food Governance}

Food governance has changed dramatically over the past two decades. Many scholars have observed that the traditional concept of law as 'command-and-control' legislation and law enforcement by national governmental bodies, including inspectorates and courts, does not adequately capture today's reality of governing food (including food safety, security and sustainability). Circumstances such as the globalization of the food chain, the growing public concern about food safety following major food crises (including BSE in the early 1990s), the increased economic power of large supermarket chains and the general perception of failing state regulation have made up a fertile ground for transitions in the governance of food.

These transitions occur both in the public and private domain. In the public domain it has been noted that various European countries have established new regulatory agencies or reformed existing ones to oversee (private) food control activities. ${ }^{1}$ At the transnational level, the European Union (EU) strengthened its food safety legislation, and established the European Food Safety Authority and the Food and Veterinary Office amongst others to improve government responses to food crises and enhance coordination between national food safety authorities to better control risks in transnational food chains. Moreover, and as various contributions to this Special Issue demonstrate, food legislation has

\footnotetext{
Paul Verbruggen is Assistant Professor of Private Law and Tetty Havinga is Associate Professor of Sociology of Law, both at Radboud University, Nijmegen.

1 Ellen Vos and Frank Wendler (eds), Food Safety Regulation in Europe. A Comparative Institutional Analysis (Antwerp/Oxford: Intersentia, 2006); Gabriele Abels and Alexander Kobusch, "Regulation of Food Safety in the EU: Explaining Organizational Diversity among Member States", in Tetty Havinga, Frans Van Waarden, Donal Casey (eds), The Changing Landscape of Food Governance (Cheltenham: Edward Elgar, 2015), pp. 39-56.
} 
moved from a rather prescriptive and legalistic approach to favour more responsive and risk-based approaches by encouraging forms of self- and co-regulation. $^{2}$

Also the private sector has responded to the challenges posed by ever-more global food supply chains and today's suspicious and responsive consumers. First and foremost, we have witnessed the emergence of retailer-driven food safety regulation and of global coalitions for setting food safety standards. ${ }^{3}$ Private food safety standards and complementing thirdparty certification have acquired a pivotal role in facilitating entry and exit in the global food supply chain. ${ }^{4}$ Private safety standards are frequently combined with standards aiming at governing externalities in food production. As the contribution by Oosterveer highlights, private food standards also aim to address externalities such as environmental degradation, the depletion of common pool resources like fish and loss of biodiversity. Also other concerns are addressed through private food standards, however, including labour conditions for farmers, animal welfare and other issues considered part of corporate social responsibility. ${ }^{5}$

2 Robyn Fairman and Charlotte Yapp, "Enforced Self-Regulation, Prescription, and Conceptions of Compliance within Small Businesses: The Impact of Enforcement", 27 Law and Policy (2005), pp. 491-519; Marian Garcia Martinez, Andrew Fearne, Julia Caswell and Spencer Henson, "Co-regulation as a Possible Model for Food Safety Governance: Opportunities for Public-Private Partnerships", 32 Food Policy (2007), pp. 299-314; Marian Garcia Martinez, Paul Verbruggen and Andrew Fearne "Risk-based Approaches to Food Safety Regulation: What Role for Co-regulation?" 16 Journal of Risk Research (2013), pp. 1101-1121.

3 Spencer Henson and John Humphrey, "The Impacts of Private Food Safety Standards on the Food Chain and on Public StandardSetting Processes", Paper Prepared for FAO/WHO May 2009, available on the internet at http://www.fao.org/docrep/012/ i1132e/i1132e00.pdf (last accessed on 16 July 2015); Errol Meidinger, "Private Import Safety Regulation", in Cary Coglianese, Adam M. Finkel, David Zaring (eds), Import Safety: Regulatory Governance in the Global Economy (University of Pennsylvania Press, Philadelphia, 2009), pp. 233-253.

4 Linda Fulponi "Private Voluntary Standards in the Food System: The Perspective of Major Food Retailers in OECD Countries", 31 Food Policy (2006), pp. 1-13; Tetty Havinga, "Private Regulation of Food Safety by Supermarkets", 28 Law and Policy (2006), pp. 515-533; Tetty Havinga, "Transitions in Food Governance in Europe. From national towards EU and global regulation and from public towards hybrid and private forms of governance", $\mathrm{Ni}$ jmegen Sociology of Law Working Papers Series 2012/02, available on the internet at http://ssrn.com/abstract=2189478 (last accessed on 16 July 2015); Terry Marsden, Andrew Flynn and Michelle Harrison, Consuming Interests: The Social Provision of Foods (London: University College London Press, 2000); Terry Marsden, Robert. Lee, Andrew Flynn and Samarthia Thankappan, The New Regulation and Governance of Food. Beyond the Food Crisis? (New York: Routledge, 2010).

5 Valerie Nelson and Anne Tallontire, "Battlefields of ideas: changing narratives and power dynamics in private standards in global
In addition to these business-to-business, industry-led standards, also private standards developed by civil society (NGOs, consumers, religious organisations and other public interest groups) have surfaced to play an important role in certain sectors. Moral standards dealing with issues of fair trade ${ }^{6}$ or religious prescriptions ${ }^{7}$ are leading examples here. At times, industry and NGOs collaborate in meta-regulatory bodies such as ISEAL to improve their methods of setting standards for food, certifying food businesses and impact analysis. ${ }^{8}$

Marsden et al have used the concept of a 'hybrid model' of food governance to describe a new balance between public and private actors in the regulation and governance of food. ${ }^{9}$ While there certainly has been a shift in the balance between public and private food regulation, we contend that both forms of regulation also increasingly interact in the governance of food related risks. For example, many private, retail-driven standards have emerged in response to changes in public food legislation, ${ }^{10}$ while public legal frameworks now also appear to respond to the importance private standards play in food supply chains. ${ }^{11}$ Oldfield, Verbruggen and Havinga most

agricultural value chains" 31 Agric Hum Values (2014), pp. 481-497; Michael J Maloni and Michael E. Brown, "Corporate Social Responsibility in the Supply Chain: An Application in the Food Industry", 68 Journal of Business Ethics (2006), pp. 35-52.

6 Laura Raynolds, "Fair Trade: Social Regulation in Global Food Markets", 28 Journal of Rural Studies (2012), pp. 276-287.

7 Shana Starobin and Erika S. Weinthal "The Search for Credible Information in Social and Environmental Global Governance: The Kosher Label", 12 Business and Politics (2010), pp. 1-35; Frans Van Waarden and Robin Van Dalen, "Halal and the Moral Construction of Quality: How Religious Norms Turn a Mass Product into a Singularity" in Jens Beckert and Christine Musselin (eds), Constructing Quality: The Classification of Goods in Markets, (Oxford, Oxford University Press, 2013), pp. 197 et sqq; Timothy D. Lytton, Kosher: Private Regulation in the Age of Industrial Food. Private Regulation in the Age of Industrial Food, (Harvard University Press, 2013)

8 Allison Loconto and Eve Foullieux, "Politics of Private Regulation: ISEAL and the Shaping of Transnational Sustainability Governance, 8 Regulation \& Governance (2013), pp. 166-185; Paul Verbruggen and Tetty Havinga, "The Rise of Transnational Private Meta-Regulators", 10 Osgoode Hall Law School Working Paper Series (2014) No. 71, available on the internet at http://ssrn.com/ abstract=2512843 (last accessed 16 July 2015).

9 Marsden et al., New Regulation and Governance of Food, supra note 4 .

10 Fulponi, "Private Voluntary Standards", supra note 4.

11 Tetty Havinga and Frans van Waarden, Veilig voedsel: Toezicht toevertrouwen? Sectorschets toezicht in de voedselsector, Report for the Dutch Scientific Council for Government Policy, (Den Haag: WRR, 2013) available on the internet at http://www.wrr.nl/ fileadmin/nl/publicaties/PDF-webpublicaties/Web_70_Havinga _DEF2010.pdf (last accessed on 16 July 2015).. 
vividly echo this trend in their respective contributions to this Special Issue. Public actors establish mechanisms of coordination and control concerning private food standards and certification schemes in order to save public resources, enhance policy outcomes or ensure transnational application of national (regional) public laws. ${ }^{12}$ In other instances, as Van der Voort demonstrates in his article, co-regulatory initiatives are introduced in which public and private actors seek to collaborate through institutional frameworks and programmes. While it must be stressed that co-regulation and other forms of hybrid governance arrangements remain the exception and most of the food governance remains either public or private in nature, these arrangements between public and private actors gain more and more importance and thus invite detailed examination.

\section{Interplay Along the Policy Cycle}

The contributions in this Special Issue are focused around the various phases of the policy cycle for food governance, thus addressing the interaction in stages of agenda-setting, rule-making, implementation, monitoring and enforcement, and evaluation and review. Several commentators have argued that a regulatory regime not only comprises legislation, rules and standards. ${ }^{13}$ Also implementation, monitoring and enforcement are constitutive to a regulatory regime. ${ }^{14}$ However, this conceptualisation fails to capture the intricacies regarding private and mixed forms of regulation. In traditional public (governmental) regulation, implementation logically follows rulemaking, as there is a legal obligation for the regulated entities to apply and carry out the rules. In the case of private regulation such automatic application or obligation to comply with the set rules is not a given. After drafting and promulgating the rules, these rules at times first need to be adopted by the regulated to bind them. Adopting a private regulatory standard is deciding to accept those rules and to commit to compliance. A private entity may decide to adopt a private regulation for several reasons: because it is legally mandatory, because compliance is made mandatory by a dominant actor in the market (such as a food retailer) or because the entity considers adoption beneficial to enter new markets, for improving its reputation, for getting a better price or some other reason.
Building on Henson and Humphrey's classification of the policy cycle for food regulation and earlier work by Havinga on regulatory arrangements in food ${ }^{15}$ we distinguish four main functions that seem to apply to every regulatory arrangement. For a regulatory arrangement to be effective, rules have to be laid down and subsequently adopted and implemented, and compliance with the rules has to be monitored and enforced. Procedures of evaluation and review complete the policy cycle and enable the evolvement of the rules and organisational learning. All regulatory activities can be thought of as part of one of these functions:

(a) Agenda setting and rule-making;

(b) adoption and implementation;

(c) monitoring compliance and enforcement and;

(d) evaluation and review.

Most literature on private and hybrid governance is focussed on the stage of agenda-setting and rulemaking, and the distribution of tasks between public and private actors therein. We expressly want to include the other phases of the policy cycle. As Van der Heijden already pointed out, the distribution of tasks and responsibilities between the participants in a hybrid form of governance may vary along the other phases of the policy cycle as well. ${ }^{16}$ Thus, interplay

12 See also: Paul Verbruggen, "Gorillas in the Closet? Public and Private Actors in the Enforcement of Transnational Private Regulation, 7 Regulation \& Governance (2013), pp. 512-532; Paul Verbruggen, Enforcing Transnational Private Regulation: A Comparative Analysis of Advertising and Food Safety, (Cheltenham, Edward Elgar, 2014).

13 Christopher Hood, Henry Rothstein and Robert Baldwin (2001), The Government of Risk. Understanding risk regulation regimes, Oxford, Oxford University Press, 2001), at p. 26-27; Kenneth W. Abbott and Duncan Snidal, "The Governance Triangle: Regulatory standards institutions in the shadow of the state", in Walter Mattli and Ngaire Woods (eds), The Politics of Global Regulation, (Princeton, NJ [etc.]: Princeton University Press, 2009), pp. 44-88, at p. 63.

14 Colin Scott, "Regulating Everything: From Mega- to Meta-regulation", 60 Administration (2012), pp. 61-89.

15 Spencer Henson and John Humphrey, "Codex Alimentarius and private standards", in Bernd Van der Meulen (ed.), Private Food Law. Governing food chains through contract law, self-regulation, private standards, audits and certification schemes, (Wageningen: Wageningen Academic Publishers, 2011), pp. 149-174, at p. 155-156; Tetty Havinga, "Conceptualizing regulatory arrangements: Complex networks and regulatory roles", in Havinga, Changing landscape of food governance, supra note 1, pp. 19-36.

16 Jeroen Van der Heijden, "Friends, Enemies or Strangers? On Relationships between Public and Private Sector Service Providers in Hybrid Forms of Governance", 33 Law \& Policy (2011), pp. 367-390. 
between public and private actors occurs within each function (e.g. a governmental organization and an industry association develop rules together or cooperate in monitoring compliance with the rules) and between two or more functions (e.g. the government sets the standards and a private organization monitors compliance).

\section{What Follows in this Special Issue}

Each article in this Special Issue represents a specific case study into the ways in which public and private actors interact, intended or unintended, in governing food related risks. The contributions seek to unravel the intimate, yet complex ties between public and private actors within mixed governance arrangements regulating food throughout the full policy cycle. They seek to discuss the interaction between public and private (both industry and civil society) that occurs in today's food governance by discussing arrangements in Europe, the United States and global supply chains. In descriptive terms, each paper lays out the 'who' (actors), the 'what' (activity), the 'why' (rationale) and the 'how' (instruments) of the particular arrangement of food governance. In evaluative terms, the papers discuss and explain the results, risks and benefits of designing public-private governance arrangements. Jointly, the contributions offer invaluable empirical insights explaining the rise, design and challenges of mixed governance arrangements in the food sector.

In the first article Michaela Oldfield discusses the adoption of the United States' Food Safety Modernization Act, which devises a federal food law regime in which the Food and Drug Administration (FDA) comes to rely on private systems of standards and third party audits for imported food. Oldfield contents that US food law consists of multiple overlapping networks of public and private actors who develop food safety regulations within multiple types of institutional venues, including private standards regimes, courts, congresses, and government regulatory agencies. She explains how various interactions within and across these networks shape and are shaped by stakeholders' interests and power relations, leading ultimately to the adoption of the FSMA in the form it took. The paper offers invaluable insights into what consequences this plurality of policy venues may have on the roles and capacities of affected stakeholders to influence governance processes and outcomes.

The contribution by Haiko van der Voort shows just how difficult it can be in practice to make a coregulatory arrangement work. In fact, his case study of the co-regulatory regime for the quality control of eggs in the Netherlands constitutes an example of coregulatory failure. Focusing on the adoption and implementation of the arrangement, Van der Voort discusses in detail the interests, concerns and dynamics that led to the design and indeed downfall of the regime. As he argues, however, the evaluation of why this happened depends on the theoretical lens applied. From a "government" perspective (implying a strong degree of hierarchy between the public and private actors concerned) potential risks to public health and safety should be erased, thus requiring a strict private inspection protocol to mirror public food inspections, including unannounced inspections and penalty fines. A "governance" perspective, by contrast, emphasises a more horizontal, networked relationship between the actors, stimulating discussion, evaluation and learning. A review of the arrangement could not overcome the stalemate that had grown between government and industry regarding the criteria and conditions to make the arrangement work. In the end, the inherently conflicting interests of the actors involved led to the demise of the co-regulatory arrangement.

The failure of co-regulation in the Dutch egg sector proved a valuable lesson in designing new governance arrangements regulating food in the Netherlands involving both public and private actors. As Verbruggen and Havinga highlight in their contribution, the Netherlands Food and Consumer Product Safety Authority (de Nederlandse Voedsel- en Warenautoriteit - NVWA) was careful to impose too rigid a policy framework on industry actors (trade associations, certification bodies and verification bureaus) when engaging with them to optimise its official riskbased monitoring and enforcement strategy. The case studies presented in the contribution focus on the ways in which the NVWA has sought to control the private control systems it enrols in its enforcement policy, something which the authors phrase as a strategy of "meta-control". The paper asks which safeguards the authority has set in place while coordinating its own activities with private food safety controls, what the advantages and risks involved in this strategy are, and to what extent this policy can be im- 
proved. From this Verbruggen and Havinga draw broader lessons for public agencies elsewhere willing to engage with private compliance mechanisms in the domain of food safety and beyond.

Finally, the article by Peter Oosterveer discusses the development of market-based standards for sustainable seafood governance and traces the interplay of these standards with public regulatory frameworks in their negotiation, drafting, implementation and enforcement. As Oosterveer contends, that interplay may lead to competition, collaboration and even hybridity across different stages in the regulatory cycle. However, in analyzing a range of sustainable food standards schemes, he finds that the bulk of the collaboration occurs in the negotiation and setting of these schemes. As regards the implementation phase Oosterveer observes both complementarity and competition, while interaction is much less prevalent in later phases of monitoring and enforcement, where separation prevails. Due to this diversification in the interplay between public and private standards in this arena, Oosterveer's outlook is that it is unlikely that harmonization between public and private sustainable seafood governance arrangements will happen in the near future.

\section{Patterns of Interplay}

The contributions in this Special Issue illustrate the fragmentation that dominates the field of food governance with multiple actors operating in multiple venues in both the domestic and the global arena. We observe public actors that facilitate or built on private food standards (Oldfield, Oosterveer), public actors who seek to engage private auditing schemes to delegate the inspection of compliance with public standards (Van der Voort) and public agencies enrolling private actors trying to develop collaborative control arrangements (Verbruggen and Havinga).

Such cooptation might lead to an increased regulatory capacity of public actors, in particular food safety agencies. That capacity is under increasing pressure due to the mismatch between global supply chains and regulatory powers that are confined to national territories, and due to consecutive rounds of cutbacks on public expenditure, thus limiting the control capacity of the state. What is more, the legal powers of (international) public actors may not extend to issues that have become increasingly impor- tant to consumers, such as sustainability in food sourcing and production. By engaging with private actors that do address those matters and facilitating their activities, as Oosterveer shows, public actors may still exert (soft) influence on the development of food governance arrangements in that arena. Oldfield highlights that the policy alternatives considered by the US legislator had been developed and tested by private food standards and voluntary programs audited by state inspectors. Finally, the public food safety authority in the Netherlands sought to strengthen its inspection capacity by employing private audit results as part of its risk-based enforcement policy (Van der Voort, Verbruggen and Havinga).

Conversely, public recognition of private arrangements might add to the regulatory capacity of private actors, more specifically the legitimacy of their schemes. Alignment with existing private arrangements by governments might enhance acceptance among market actors and other private stakeholders (Oosterveer, Oldfield). In other cases, however, governmental policy may face legitimacy concerns because of a potential risk of capture (Verbruggen and Havinga). In particular, the case study presented by Van der Voort shows that developing and maintaining a collaborative governance arrangement is a delicate job that requires sound judgement in balancing the different interests of all participants, together with the protection of the public interests involved.

The papers reveal two other issues that affect the interplay between public and private actors, and it's course of events, namely the economic interests of the actors involved and their yearning to retain a degree of authority over the governance arrangement and in particular over the own responsibilities and obligations therein. Not surprisingly, economic interests are an important motivation for the actors to engage with each other. Owners of private standards and schemes are keen to increase their market shares and achieve efficiencies for clients and participating food business (Van der Voort, Verbruggen and Havinga). Accordingly, they support governance arrangements that benefit their economic interests and are reluctant to amend their standards and schemes that do not align their interests. Efficiency concerns are also important drivers for public actors, but perhaps less dominant than for industry actors. Governments may collaborate with private parties in order to improve access of domestic food products to export markets, as in the case of sustainable fish (Oosterveer), 
or to save public spending by way of transferring the costs of audit and control to the industry (Van der Voort, Verbruggen and Havinga). A more dominant driver for collaboration among public actors, however, appears to be the goal to enhance regulatory capacity, or minimise the loss of such capacity in the face of global supply chains and budgetary constraints (Oldfield, Van der Voort, Verbruggen and Havinga).

In addition to economic interest, the case studies presented in the articles also draw attention to the desire of the actors to retain a degree of authority over the responsibilities they assume under the arrangement. Public actors certainly want to feel in control over essential elements of the governance arrangement (Oldfield, Van der Voort, Verbruggen and Havinga) and determine the conditions for collaboration. If private actors do not align, they are inclined to pull the plug on a co-regulatory arrangement. Private actors, for their part, mount resistance if the conditions interfere with their way of doing business, as Oldfield shows in her analysis of the opposition from small farm and sustainable agriculture that nearly blocked the discussed legislative reform in the US. Van der Voort attributes the failure of the co-regulatory arrangement for the control of the quality of eggs in the Netherlands to the resentment from eggfarmers and the private body responsible for the arrangement vis-à-vis the public actors involved, which were felt to dictate the details of the arrangement and curb the economic interest of the sector (the costs of the required additional audits).

Accordingly, a proper co-regulatory arrangement constitutes a difficult balancing act of all interests involved, also those potentially conflicting. What is more, the arrangement is not a static unit, but involves a dynamic process in which actors and interests enter and leave the scene. Managing and aligning those interests presupposes sound communication between the actors involved, which turns out to be a real challenge in practice. The contributions to this Special Issue offer the reader key insights in just how public and private actors go about this joint undertaking and the problems they face along the way. 